\title{
Research
}

\section{Integrating Traditional Ecological Knowledge and Ecological Science: a Question of Scale}

\author{
Catherine A. Gagnon $^{1}$ and Dominique Berteaux ${ }^{1}$
}

\begin{abstract}
The benefits and challenges of integrating traditional ecological knowledge and scientific knowledge have led to extensive discussions over the past decades, but much work is still needed to facilitate the articulation and co-application of these two types of knowledge. Through two case studies, we examined the integration of traditional ecological knowledge and scientific knowledge by emphasizing their complementarity across spatial and temporal scales. We expected that combining Inuit traditional ecological knowledge and scientific knowledge would expand the spatial and temporal scales of currently documented knowledge on the arctic fox (Vulpes lagopus) and the greater snow goose (Chen caerulescens atlantica), two important tundra species. Using participatory approaches in Mittimatalik (also known as Pond Inlet), Nunavut, Canada, we documented traditional ecological knowledge about these species and found that, in fact, it did expand the spatial and temporal scales of current scientific knowledge for local arctic fox ecology. However, the benefits were not as apparent for snow goose ecology, probably because of the similar spatial and temporal observational scales of the two types of knowledge for this species. Comparing sources of knowledge at similar scales allowed us to gain confidence in our conclusions and to identify areas of disagreement that should be studied further. Emphasizing complementarities across scales was more powerful for generating new insights and hypotheses. We conclude that determining the scales of the observations that form the basis for traditional ecological knowledge and scientific knowledge represents a critical step when evaluating the benefits of integrating these two types of knowledge. This is also critical when examining the congruence or contrast between the two types of knowledge for a given subject.
\end{abstract}

Key Words: Arctic; Inuit; protected area; scale; Chen caerulescens atlantica; traditional ecological knowledge; Vulpes lagopus; Alopex lagopus; local ecological knowledge; scientific knowledge

\section{INTRODUCTION}

As defined by Berkes (2008:7), traditional ecological knowledge or TEK encompasses (1) factual knowledge about ecological components and processes, (2) knowledge put into practices of environmental use, and (3) the cultural values, ethics, and philosophies that define human relationships within the natural world (Stevenson 1996, Usher 2000, Houde 2007). To various degrees, all these TEK "categories" have contributed to environmental research and management by improving baseline data on species and ecological processes (Nakashima 1991, Ferguson et al. 1998, Mallory et al. 2003), by providing insights that can be used to develop alternative resource management systems (Berkes and Folke 1998, Turner et al. 2000, Berkes 2008), or by renewing conservation ethics (Berkes 2008).
It has been recognized that TEK may improve resource management, and many ecological assessments and management policies now require the integration of TEK and scientific knowledge (Mauro and Hardison 2000, Usher 2000). The benefits (Berkes 2008, Huntington 2000) and challenges (Agrawal 1995, Nadasdy 2003) of this co-application have led to extensive discussions over the past decades. Nevertheless, work is still needed to diversify and refine methods that make it possible to integrate TEK and scientific knowledge (Huntington et al. 2004a, Bart 2006).

Ecological systems operate on a multitude of spatial and temporal scales (Wiens 1989, Levin 1992, 2000), and understanding how processes differ and interact among these scales is one of the great difficulties of ecological research (Wilbanks 2006). An observer can usually specialize in only a subset 
of existing scales because of the nature of economic motivations, time and logistical constraints, or personal and cultural interests. In particular, scientists and local community members usually have very different motives and access to different observational equipment for studying the natural world.

The most common approach to integrate TEK and scientific knowledge has been to compare factual ecological observations from similar temporal and spatial scales (Huntington et al. 2004a, Gilchrist et al. 2005, Fraser et al. 2006). When applicable, this approach helps to identify the strengths and weaknesses of the information derived from either type of knowledge, signaling gaps in overall knowledge and exposing new research needs (Huntington et al. 2004a,b, Gilchrist et al. 2005). However, a different and less investigated method proposed by Huntington et al. (2004b) focuses on "complementarity rather than concordance in spatial perspectives."

The scales characterizing TEK and science are largely defined by the questions that are asked and the methodologies that are selected, rather than by intrinsic differences between these two types of knowledge. Nevertheless, TEK has generally been recognized as differing from science because it is based on information acquired during longer time series but over smaller and more specific localities (Johnson 1992, Riedlinger and Berkes 2001, Moller et al. 2004). Therefore, TEK usually provides a longer temporal perspective but a more geographically restrained view of the system being studied, although this may not always be the case (Table 1). In the Canadian High Arctic, because of the harsh climate encountered during the winter and the migration behavior of certain species, scientific wildlife research has usually been performed during the spring and summer seasons. The costs of traveling in the Arctic have also restrained most studies to one or a few sites, producing detailed yet locally specific data. Because of the Inuit's long history of year-round travel and use of large areas, it is reasonable to expect that combining Inuit TEK, which is one aspect of Inuit cultural knowledge or Inuit Qaujimajatuqangit, with scientific knowledge should increase our overall understanding of Arctic ecology.

In this study we explore the idea of integrating TEK and scientific knowledge by emphasizing their complementarity across spatial and temporal scales.
We present case studies dealing with two wildlife species from the eastern Canadian Arctic. For each species we used our knowledge of the scientific literature and of the local use of natural resources to document TEK, emphasizing spatial and temporal scales that have been poorly investigated by scientific research. We then determined if and how our approach expanded currently documented knowledge and assessed the validity of this approach. When scientific knowledge and TEK were available at similar scales, we also compared these two types of knowledge. To keep this study within our field of expertise and logistical capabilities, we did not include the spiritual and value-based aspects of TEK, although this is an area of potentially great complementarity with science.

\section{METHODS}

\section{Study area, people, and general context}

Our work was performed in collaboration with Inuit elders and hunters from Mittimatalik $\left(72^{\circ} 40^{\prime} \mathrm{N}, 77^{\circ}\right.$ $\left.58^{\prime} \mathrm{W}\right)$, also known as Pond Inlet, a community of 1200 people located on north Baffin Island, Nunavut, Canada (Fig. 1). According to archaeological evidence, modern Inuit and their ancestors have lived nomadically in the Mittimatalik area for approximately $4000 \mathrm{yr}$ (MaryRousselière 1985). It is only in the decade following the establishment of a federal school in 1959 that most Inuit families settled in the permanent community.

For most of the 20th century, people from the Mittimatalik area participated actively in trading the furs of arctic foxes (Vulpes lagopus). Even after settlement, fur trading remained an important economic activity until the collapse of the fur market in the 1980s (Robinson 2005). Today, Mittimatalik has a mixed economy consisting of wage salaries, transfer payments, and land-based subsistence activities. The latter are usually associated with ringed seal (Phoca hispida), bearded seal (Erignathus barbatus), narwhal (Monodon monocerus), caribou (Rangifer tarandus), polar bear (Ursus maritimus), arctic char (Salvelinus alpinus), greater snow goose (Chen caerulescens atlantica), and arctic fox (Riewe 1992, Priest and Usher 2004). The main spoken language in the community remains the native language, Inuktitut, although English is known by a large portion of the population. 
Table 1. Representative examples of studies combining traditional ecological knowledge (TEK) and scientific knowledge. The summary describes whether TEK provided a smaller/larger or shorter/longer scale of spatial and temporal information compared to available scientific knowledge.

\begin{tabular}{lcccc}
\hline \hline Research subject & Study location & Spatial scale & $\begin{array}{c}\text { Temporal } \\
\text { scale }\end{array}$ & References
\end{tabular}

Winter ecology and habitat use of Common eider (Somateria mollissima sedentaria)

Biodiversity conservation in populations of Brook charr (Salvelinus fontinalis)

Ecology, behavior, harvest trends, and causes of population decline of sooty shearwater (Puffinus griseus)

Identification of essential fish habitats for several groundfish species

Flooding, ecology, and environmental management history of a wetland targeted for rehabilitation

Movement and population decline of white-winged and surf scoters (Melanitta fusca and M. perspicillata)

Historical changes in distribution and abundance of a population of arctic tundra caribou (Rangifer tarandus)

Conservation of bumphead parrotfish (Bolbometopon muricatum)

Trends in harvest, behavior, and migrating movements of Atlantic cod and lumpfish (Gadus morhua and Cyclopterus lumpus)

Ecology of arctic fox (Vulpes lagopus) and greater snow geese (Chen caerulescens atlantica)
Belcher Islands, Canada

Mistassini Lake, Canada

Rakiura, Poutama, and Titi Islands, New Zealand

Irish Sea, UK

Kanyapella Basin, Australia

Alaska, USA, and Northwest Territories, Canada

South Baffin Island, Canada

West Solomon Islands

Newfoundland, Canada

North Baffin

Island, Canada
Smaller geographical area

Smaller geographical area

Smaller geographical area

Smaller geographical area

Smaller geographical area

Smaller geographical area Larger
geographical
area

Longer time series

Smaller geographical area

Smaller geographical area

\footnotetext{
Larger geographical

area
} series

Longer time

Longer time series

Longer time series

$\ldots$

Longer time series
Gilchrist et al. (2005)

Gilchrist et al. (2006)

Fraser et al. (2006)

Lyver (2002)

Robertson and McGhee (2003)

Huntington et al. (2004)

Aswani and Hamilton (2004)

(1998)
Longer time

Longer time series

Neis et al. (1999)

This study 
Fig. 1. Study area. (A) Close-up of the study area showing north Baffin Island and Bylot Island, Nunavut, Canada. The community of Mittimatalik is the closest and largest settlement located near the Sirmilik National Park of Canada (lighter beige). (B) Location of the Nunavut territory (darker beige), in which the red circle indicates the general study area location.

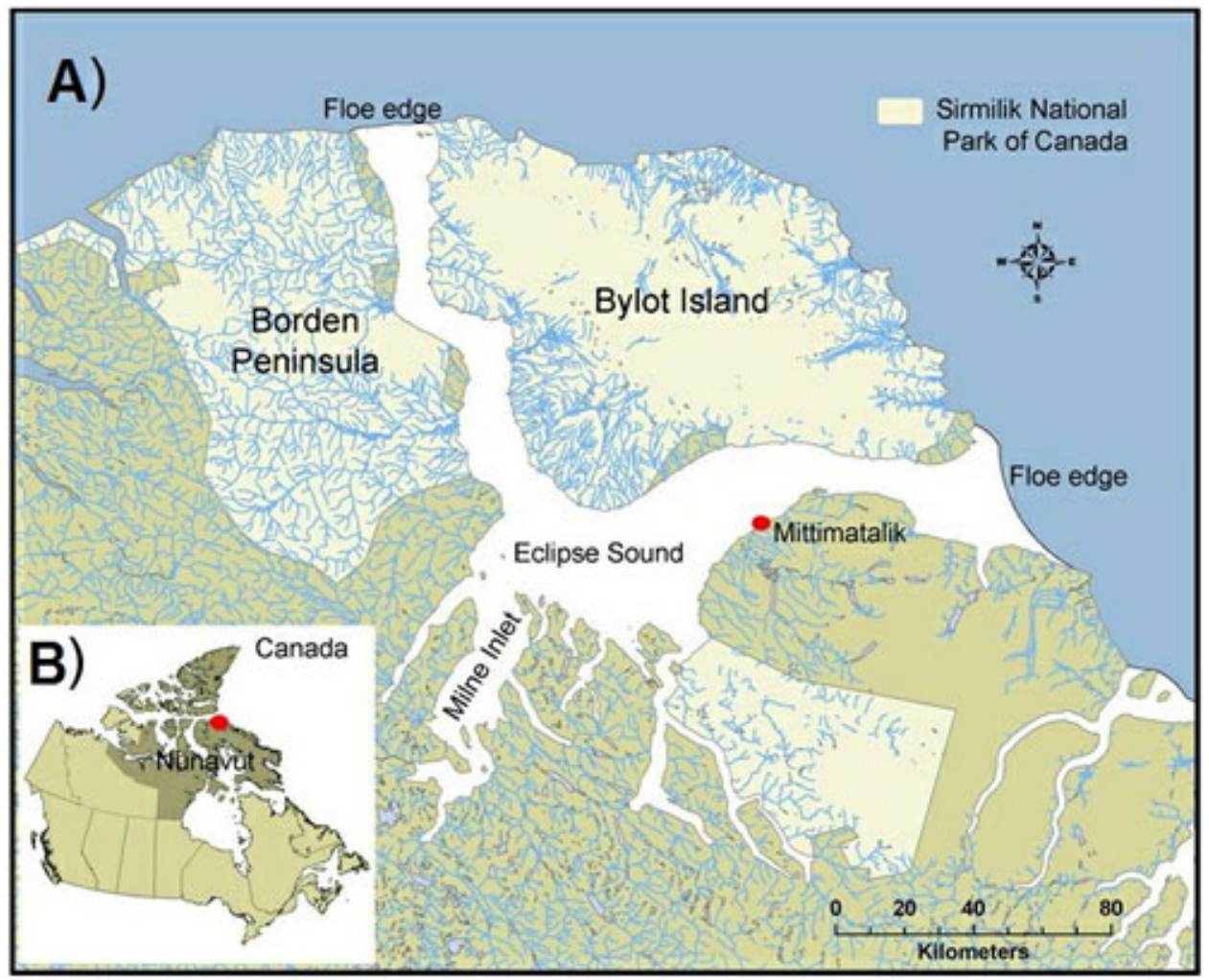

In 2001, Sirmilik National Park of Canada (Sirmilik NPC) was created, and its boundaries include Bylot Island and sections of northern Baffin Island. Biophysically, the park is characterized by mountainous and glaciated terrains, deep fjords, and a fauna and flora typical of the Arctic Cordillera and Northern Arctic ecozones (Environment Canada 2005). Bylot Island is also the largest known breeding site for greater snow geese worldwide (Reed et al. 1998). As the main users of the park, the community of Mittimatalik participates in the co-management of Sirmilik NPC. Parks Canada launched an Inuit knowledge project (Inuit Knowledge Project 2009) in 2004 to increase the inclusion of Inuit TEK into the understanding and management of Nunavut parks. We worked in collaboration with the Parks Canada Inuit Knowledge Project, which allowed us to benefit from the guidance of the Mittimatalik Inuit Knowledge Working Group. This group contained three elders and one youth from the community and served as an overseeing body to ensure that our study addressed local interests. We interacted with members of the Mittimatalik Inuit Knowledge Working Group as frequently as possible through meetings $(n=3)$, written updates, and informal discussions. See Gagnon and Berteaux (2006) for further details regarding the political and scientific context of this study.

Our study concentrated on knowledge about arctic foxes and greater snow geese, or tiriganiaq and kanguq, respectively, in Inuktitut. These two species were studied because people from Mittimatalik hunt them and expressed their desire to contribute knowledge about them. Both species 
are also important components of the local terrestrial ecosystem (Gauthier et al. 1996, Bêty et al. 2002) and have been extensively studied by scientists in the area, which allowed for knowledge integration at the same population level. Finally, arctic foxes and snow geese were species for which management was not a source of conflict; this greatly facilitated our study (Fig. 2).

\section{Review of scientific information}

The autoecology of a species can be decomposed into a large number of themes and subthemes, and how these categories are defined is largely subjective. Here, we investigated three categories of information for each species. For arctic fox, we looked at winter feeding, denning areas, and the arrival of red fox (Vulpes vulpes) in the area. For snow geese, we considered the molting cycle, fall migration, and trends in numbers and distribution. These categories represent important components of each species' local ecology, as well as areas of interest to both scientists and local experts, that could potentially provide large amounts of complementary information. For each topic, we performed a thorough review of published and unpublished scientific information, and determined whether research had been performed at the local study site or elsewhere nationally and internationally. Five scientists who were experts on foxes and four who were experts on geese were also consulted to ensure that all available knowledge to date was reviewed. A brief resume of available scientific information is given in the results section, and more detailed reviews are provided in Appendix 1.

\section{Collection of Inuit traditional ecological knowledge}

The TEK aspect of our study was initiated by two consultation meetings held in Mittimatalik in February and March of 2005. Upon approval from the community, we documented TEK using several qualitative research approaches that included workshops, semi-directive interviews, mapping, focus groups, participatory observations, and an elders-youth camp (Grenier 1998, Huntington 1998). These were spread over four visits to Mittimatalik from February 2005 to July 2006, for a total of seven months spent in the community (see
Gagnon 2007 for details). A final community presentation was also given in Mittimatalik in March 2008.

We started the first phase of TEK collection using semi-directive interviews (Grenier 1998, Huntington 1998), a method that allows unanticipated information to emerge (Ferguson and Messier 1997, Huntington 1998). Between May and September 2005, we interviewed 21 persons considered local experts on geese, foxes, and the land. Interviews opened with questions about the informant's place of birth and and the seasonal hunting and traveling areas he was most familiar with. This provided a temporal and spatial context for the information collected later on topics related to the ecology and natural history of foxes and geese, their current and traditional uses, and their cultural importance (see Appendices 2 and 3). With the assistance of a professional interpreter, we conducted the interviews in both English and Inuktitut. Being born and raised in Mittimatalik, the interpreter helped identify exact geographical locations and associated place names, stimulated conversations, and minimized the likelihood of translating errors because of differences in local dialects. As recommended by the elders, a local student was hired to record the interviews on video.

\section{Analysis and verification of data}

We analyzed the English transcripts of the interviews by codifying segments of the transcripts according to the topic(s) they covered, using both deductive (predefined) and inductive (defined a posteriori) coding (Miles and Huberman 2003). We also digitized and georeferenced all the spatial information to produce comprehensive maps.

To begin the validation of our results (Creswell 1998), we worked in Mittimatalik from May to July of 2006 with a local research assistant to clarify confusing segments of the interviews and to discuss interpretations. Four verification workshops were organized on 20-22 June, each with four participants who were elders and/or hunters, to confirm and discuss our findings. From 11 to 17 June 2006, we also participated in an elder-youth camp we had organized in collaboration with the local elders' committee. A total of 18 participants attended the camp, including six elders and/or hunters, 10 youth, and two researchers. Focus 
Fig. 2. A conceptual graph showing how the level of the local community's interest in and contact with a given species influences the ease with which it is possible to gather traditional ecological knowledge (TEK) about this species. When a community has little interest in or contact with a given species, e.g., some cryptic insects, TEK is low and therefore cannot be gathered productively (left side of the curve). Conversely, when the community is highly interested in a species, issues surrounding this species can be locally strongly politically charged, e.g., polar bears in some communities, and TEK can become difficult to acquire without bias (right side of the curve), although responses can be broad and diverse. The arctic fox and greater snow geese studied here provided an ideal context to collect TEK (gray area, center of the graph), because both species are visible and harvested but do not incite strong reactions.

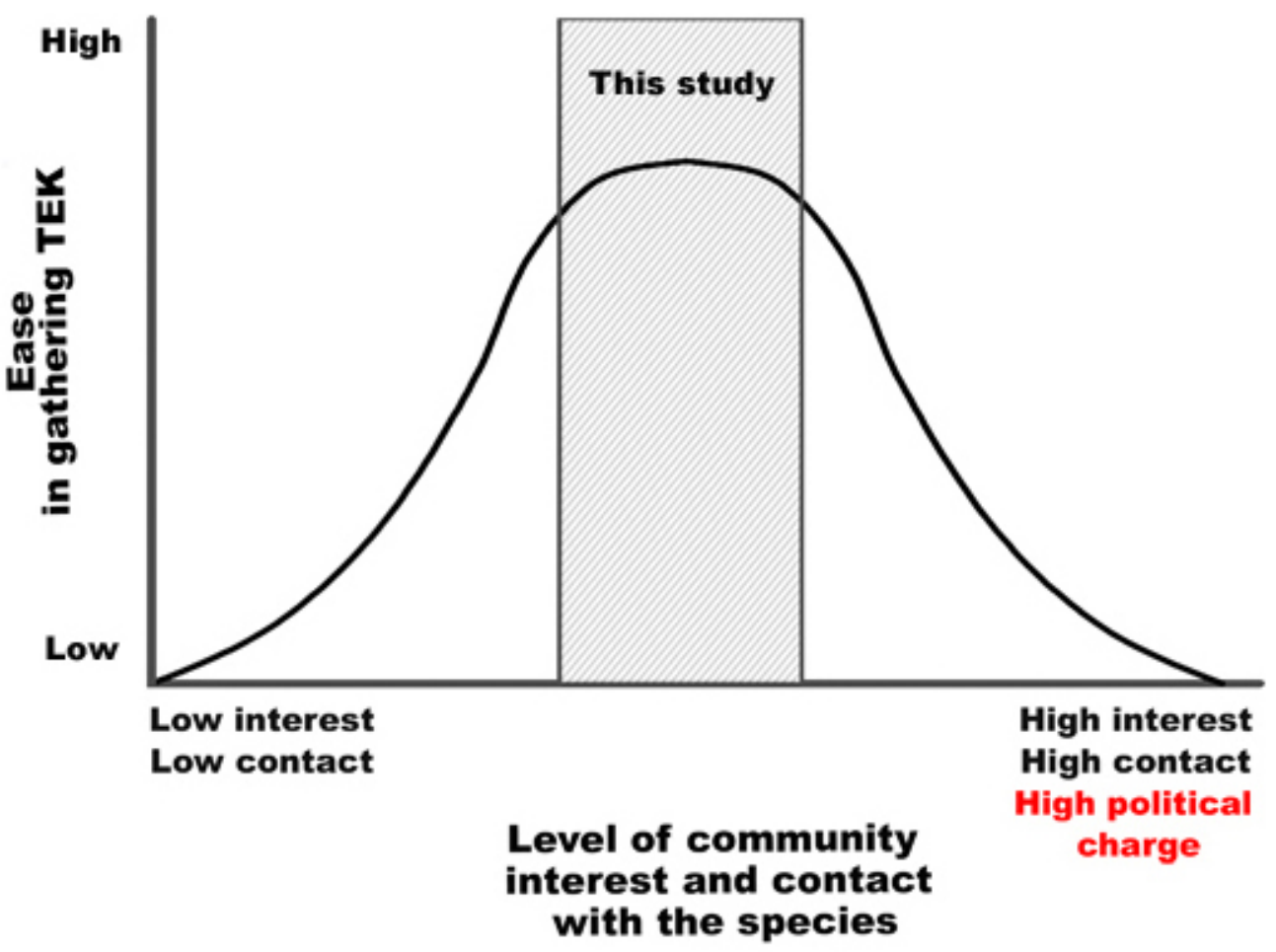

groups and informal discussions held during the camp allowed us to evaluate the congruence of information gathered using different approaches (Creswell 1998).

Unless stated otherwise, we report results based on first-hand observations provided by the informants. Because we used semi-directive interviews, answers from local experts did not always address every topic. Consequently, when appropriate, we present the results as frequencies of informants' observations about a topic, in the form of the ratio of the number of informants who made a particular observation to the number of informants who did discuss the topic pertaining to the observation. Such frequencies provide relative indices about the level of agreement for particular observations. When the potential for confusion exists in the interpretation of these ratios, we specify who was not included in the numerator and/or denominator. For each topic, it is possible that the sum of the numerators may be greater than the denominator in situations in which observers provided more than one specific observation or detail. We excluded from the analyses any observations made by an informant who had explicitly mentioned his lack of knowledge about the specified topic. 


\section{CASE STUDIES}

\section{Winter feeding ecology and distribution of the arctic fox}

According to 16 local experts who mentioned at least one item eaten by arctic foxes, the winter diet of arctic foxes is made up of items from various sources. Of these experts, 11/16 mentioned lemmings (Dicrostonyx groenlandicus and Lemmus trimucronatus), 12/16 mentioned carcasses of sea mammals, 2/16 referred to caribou (Rangifer tarandus), and 1/16 cited arctic hare (Lepus arcticus). One expert said that artic foxes eat birds, although the species were not identified, and another referred to food caches. Three of the 16 experts called foxes scavengers who feed on, according to one expert, anything they can find. Of the dozen informants who indicated that arctic foxes fed on the carcasses of sea mammals, 7/12 specified that the animal remains originated from beached animals, 5/12 said that they were leftovers from polar bear kills, and 3/12 referred to carcasses left behind by hunters. Some informants did not specify the origin of the carcasses, whereas others identified more than one source.

When discussing the winter diet of arctic foxes, 11 of 21 informants reported the existence of two overwintering strategies used by arctic foxes, one involving mainly the use of tundra and the other the use of sea ice. The remaining 10 informants did not report on this topic. The 11 informants who commented on these two strategies also mentioned one or more physical characteristics that distinguished the two types of foxes. Of the respondents commenting on the "land" fox, 8/11 said that it had thicker fur, 4/11 reported that its fur was whiter, and 1/11 described its fur as longer. Two of the 11 said that the land fox was larger, and one each said that it had less oily fat, had a thinner skin, was better to eat, and turned white earlier in the winter. For each characteristic, the experts left out of the numerator, e.g., 3/11 for thicker fur, did not report on the variable. Seven out of 11 informants provided potential reasons for the physical variations between the land and "sea" fox, whereas the remaining four did not comment. Six out of seven mentioned differences in food sources as the main reason, and one of the seven stated that temperature differences between the floe edge and the land could explain variations in fur thickness. While discussing this phenomenon during verification workshops, informants stated that land foxes were generally trapped on the mainland and at the end of inlets, whereas sea foxes were mostly trapped at the floe edges (Fig. 3).

A large proportion of informants (17 of 21) also reported on a migration occurring in March-April, during which foxes move toward the sea ice to feed on newborn ringed seal pups. The remaining four informants did not raise this topic.

The winter diet of arctic foxes has rarely been quantified (Roth 2002), and there is currently no scientific information regarding the winter feeding habits of arctic foxes from the Mittimatalik area. Based on studies conducted elsewhere, the arctic fox is considered an opportunistic omnivore (Fay and Stephenson 1989, Angerbjörn et al. 1994, Roth 2002, Eide et al.2005), and its winter diet can consist of various items depending on the habitat occupied (see Appendix 1 for details). Studies have suggested that two foraging strategies, one terrestrial and one marine, may be adopted by different segments of arctic fox populations, although this has not been shown to occur in the winter (Roth 2002; see Appendix 1).

Scientists have also documented that arctic foxes may prey on ringed seal pups by entering their subnivean birth lairs in the spring (Smith 1976, Hammill and Smith 1991, Furgal et al. 1996). Although this behavior has been recorded in Admiralty Inlet, about $250 \mathrm{~km}$ west of Mittimatalik, low predation rates were reported (Furgal et al. 1996).

\section{Arrival of the red fox in the area}

When 21 interview subjects were asked about the first time they sighted red foxes in the Mittimatalik area, only 17 were able to comment. Of those, 13/17 remembered the first time they had seen a red fox. For one, it was in 1943 near Igloolik; 2/13 first saw red foxes in 1947-1948 near Mittimatalik; 8/13 had their first sighting during the 1950 s and $2 / 13$ in the 1960s. Of the remaining informants, three remembered having always seen an occasional red fox and one observer believed that they had always been around, based on his father's comments.

From a scientific perspective, a northward expansion in the distribution of red foxes has been observed in North America, Europe, and Eurasia over the last century (Macpherson 1964, Chirkova 1968). This coincided with a reduction in the abundance and distribution of arctic fox (Chirkova 
Fig. 3. General spatial distribution of "land" and "sea" arctic fox (Vulpes lagopus), according to the traditional ecological knowledge reported by local experts from Mittimatalik, Nunavut, Canada.

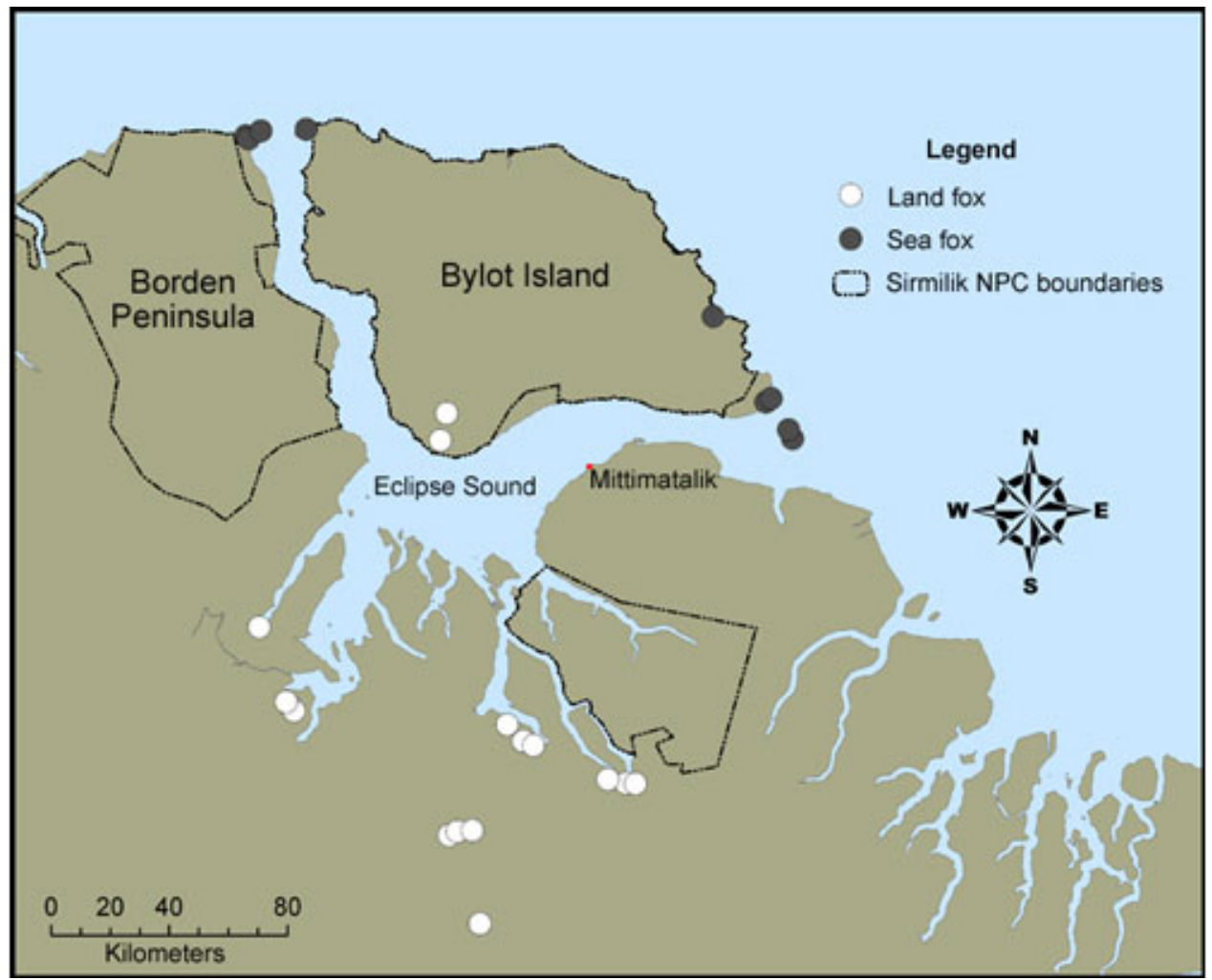

1968, Angerbjörn et al. 1994). This reduction motivated many investigations, mainly in Europe, to examine the relationship between the two species (see Appendix 1).

Pelt records are the only published information regarding the colonization of Baffin Island by red foxes (Macpherson 1964). According to these approximate records, red foxes were present on south Baffin Island around 1918 and reached Mittimatalik and Arctic Bay in 1947 and 1948, respectively (Macpherson 1964). The first scientific mention of a red fox on Bylot Island dates from 1977 (Kempf et al. 1978).

\section{Locations and characteristics of arctic and red fox denning areas}

Many denning locations, for both arctic and red foxes, have been reported by local experts (Fig. 4).
Of the experts, 17/21 described the characteristics that define a good denning habitat, 13/17 mentioned the need for sandy soil or a sandy area, $2 / 17$ referred to the presence of fish, and one each mentioned places with soil, low-lying areas, and little hills where foxes can dig. The other four informants did not report on these variables.

Detailed scientific investigations of fox dens have been performed on a $425-\mathrm{km}^{2}$ study area on Bylot Island (Szor et al. 2008). Analyses of 83 dens revealed that dens were preferably excavated on mounds or steep slopes with southern exposures, in the proximity of streams, and on sandy substrates (Szor et al. 2008). Dens were also preferentially located at sites with a high ground temperature, high depth to permafrost, and low snow cover in spring. Of the 83 dens, 27 had been used at least once for reproduction between 2003 and 2005. Analysis revealed that, although food resources positively influenced the selection of reproductive dens, arctic 
Fig. 4. Locations of arctic fox (Vulpes lagopus) and red fox (V. vulpes) dens and denning areas, as reported by the local experts from Mittimatalik, Nunavut, Canada, interviewed in this study.

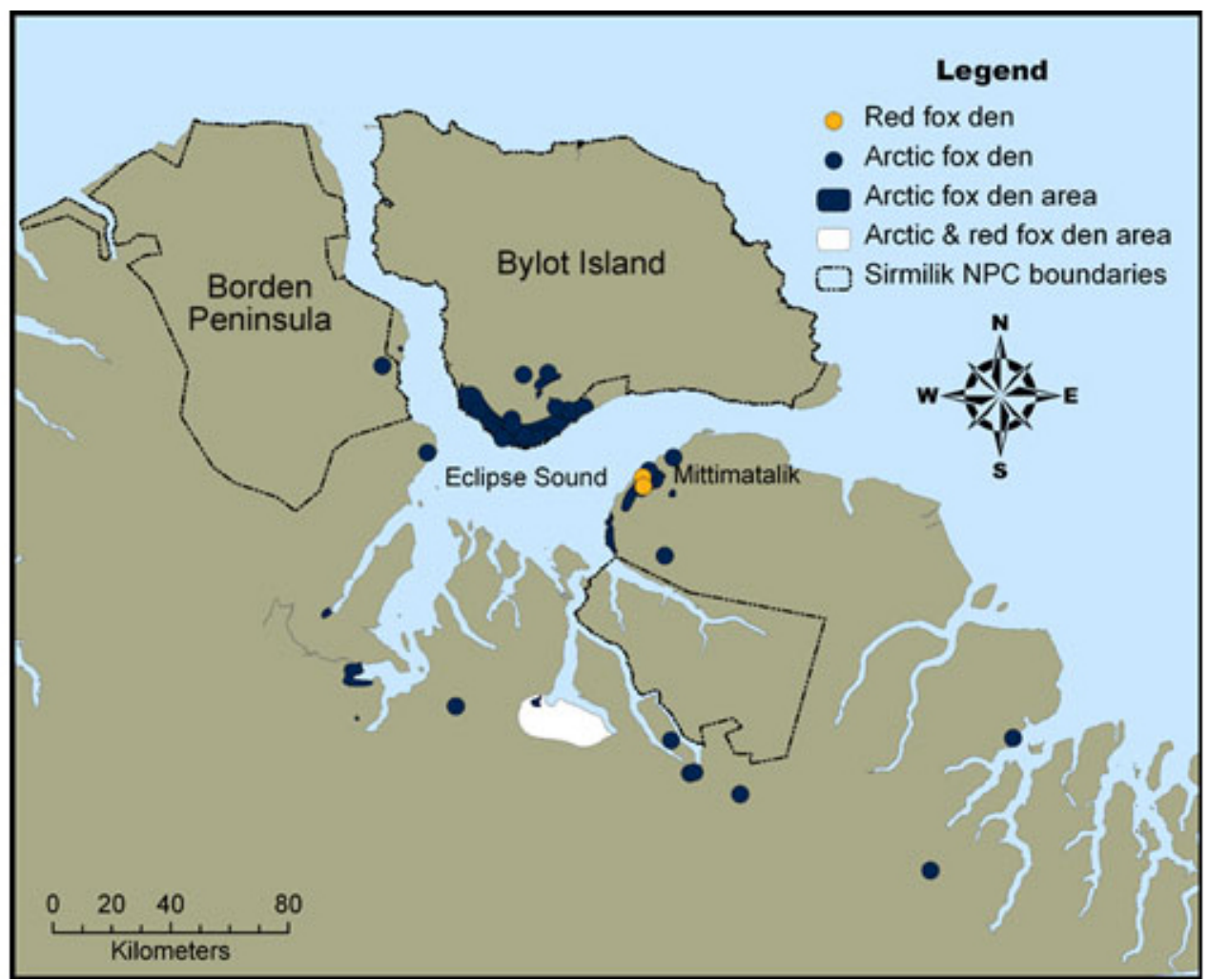

foxes tended to avoid reproducing in dens located in the vicinity of other dens (Szor et al. 2008). Characteristics of arctic fox dens investigated in other arctic regions are consistent with the findings of Szor et al. (2008; see Appendix 1).

\section{Molting cycle of greater snow geese}

Of the 14 informants familiar with the molting cycle of geese, 12/14 mentioned that non-nesting geese molt earlier in the season than do nesting geese, and the other two did not comment on the relative timing of molt for breeding vs. nonbreeding geese. Nine of these 14 informants provided information about the time of year during which non-nesting geese molt, indicating that molt occurs through the month of July. In addition, seven of these nine informants gave more specific information: $6 / 7$ specified that non-nesting geese start molting at the end of June, and $1 / 7$ reported that they start in the middle of July. For nesting geese, 10 informants stated that the timing of the molt generally corresponded with the time when goslings have hatched and grown bigger, which, according to one of these 10 informants is around the middle of July. Of the remaining four informants, one was interviewed on 26 July and mentioned that nesting geese would molt later than the interview date. The other three were interviewed on 27 July, 5 August, and 9 August, and said that nesting geese were in the midst of molting during the time of their interviews.

Various observations regarding molting locations for nesting and non-nesting geese were recorded (Fig. 5). Of 14 informants providing comments on molting locations, 4/14 indicated that they did not know if non-nesting geese went to a particular site to molt, 4/14 stated that nesting and non-nesting geese never molt together, one denied any 
knowledge of whether these two segments of the goose population molt together, and one stated that they both molt on Bylot Island. Nesting geese were reported to gather around ponds by two respondents, and three said that non-nesting geese molt on higher ground. Finally, of seven informants who discussed changes in goose molting locations, 4/7 mentioned that there had been no change in molting locations in the past several decades, whereas $3 / 7$ could not give an opinion because they had not been to their regular goose hunting grounds recently.

There are no published scientific data regarding the molt of geese from Bylot Island. Field observations performed on Bylot and studies performed elsewhere revealed that nesting geese start molting two to three weeks after goslings have hatched, and molt lasts around three weeks (Mowbray et al. 2000, G. Gauthier, personal communication). Based on reproductive data from Bylot Island (Gagnon et al. 2004), breeding geese should usually start to molt around 31 July and regain flight around 20 August, but this may vary (Bêty et al. 2003; see Appendix 1).

Approximately $90 \%$ of radio-collared female geese that did not nest or had failed in their nesting attempt departed Bylot Island between the end of June and the middle of July to molt elsewhere (Reed et al. 2003). Nevertheless, in 1999, around 700 non- or failed nesting geese were observed molting on the Island on 15 July, and five geese were believed to have completed their molt between 31 July and 8 August (Reed et al. 2003). Large concentrations of molting geese, most of them non- or failed nesters, were observed in 1993, 2006, 2007, and 2008 in an area located approximately $200 \mathrm{~km}$ south of Bylot Island (A. Reed and M. R. Evans, personal communication). However, it is unclear if these geese were present on Bylot Island earlier in the summer, prior to molting (G. Gauthier, personal communication). According to Abraham (1980), studies performed in the Hudson Bay have also shown spatial differences in molting between nesting and non-nesting lesser snow geese (Chen caerulescens caerulescens).

\section{Goose migration: timing of fall migration, routes, and stopover sites}

Sixteen of 21 informants indicated that they were familiar with goose migration. Most of them identified consistent periods during which geese leave on fall migration: 13/16 informants stated that geese start to leave at the end of August through September, and 3/16 said that they leave after molting. According to 15 of these 16 experts, geese do not leave simultaneously, but rather in small groups; the other expert had no comment. Geese reportedly follow similar paths during the fall and spring migrations, flying along a north-south axis that passes over the fjords and inlets of north Baffin Island (Fig. 6). Several stopover sites were identified in the north Baffin fjord lowlands in which geese are said to gather and feed before resuming their migration.

The scientific information available regarding the migration pattern of geese nesting in the High Arctic is based on five reproductively successful female greater snow geese tracked by satellite telemetry from Bylot Island to their wintering grounds $(\mathrm{G}$. Gauthier, personal communication). The tracked birds departed Bylot Island between 28 August and 3 September, spending a few days on the north coast of Baffin Island before flying south (Blouin 1996; see Appendix 1). Surveys performed in 2006, 2007, and 2008 also suggest that Steen Bay, approximately $250 \mathrm{~km}$ south of Bylot Island, may be an important stopover site for geese migrating to Bylot Island in the spring (M. R. Evans, personal communication).

\section{Trends in goose population size and distribution}

Descriptions of local size variations in the goose population were not consistent among the 12 informants who commented on this topic: $4 / 12$ stated that the numbers remained unchanged, $2 / 12$ mentioned an increase, 2/12 mentioned a decline, and $4 / 12$ said that they did not know (Table 2). Four out of 12 further reported that the goose population always varied between years (Table 2). Increases and decreases in goose abundance have been recorded for various locations (Fig. 7, Table 2).

Twelve of 15 informants reporting on the distribution of geese indicated that geese are more widely dispersed now than they were in the past. The other three informants did not indicate whether geese are currently more or less dispersed. Only one informant did not recall any changes in goose distribution (Table 2). During verification workshops, the general consensus was that geese are more dispersed than they were in the past. 
Fig. 5. Molting locations for nesting and non-nesting greater snow geese (Chen caerulescens atlantica), as reported by the local experts from Mittimatalik, Nunavut, Canada, interviewed in this study. Informants did not specify the breeding status (nesting, non-nesting, or both) of molting geese encountered on locations marked as "undetermined."

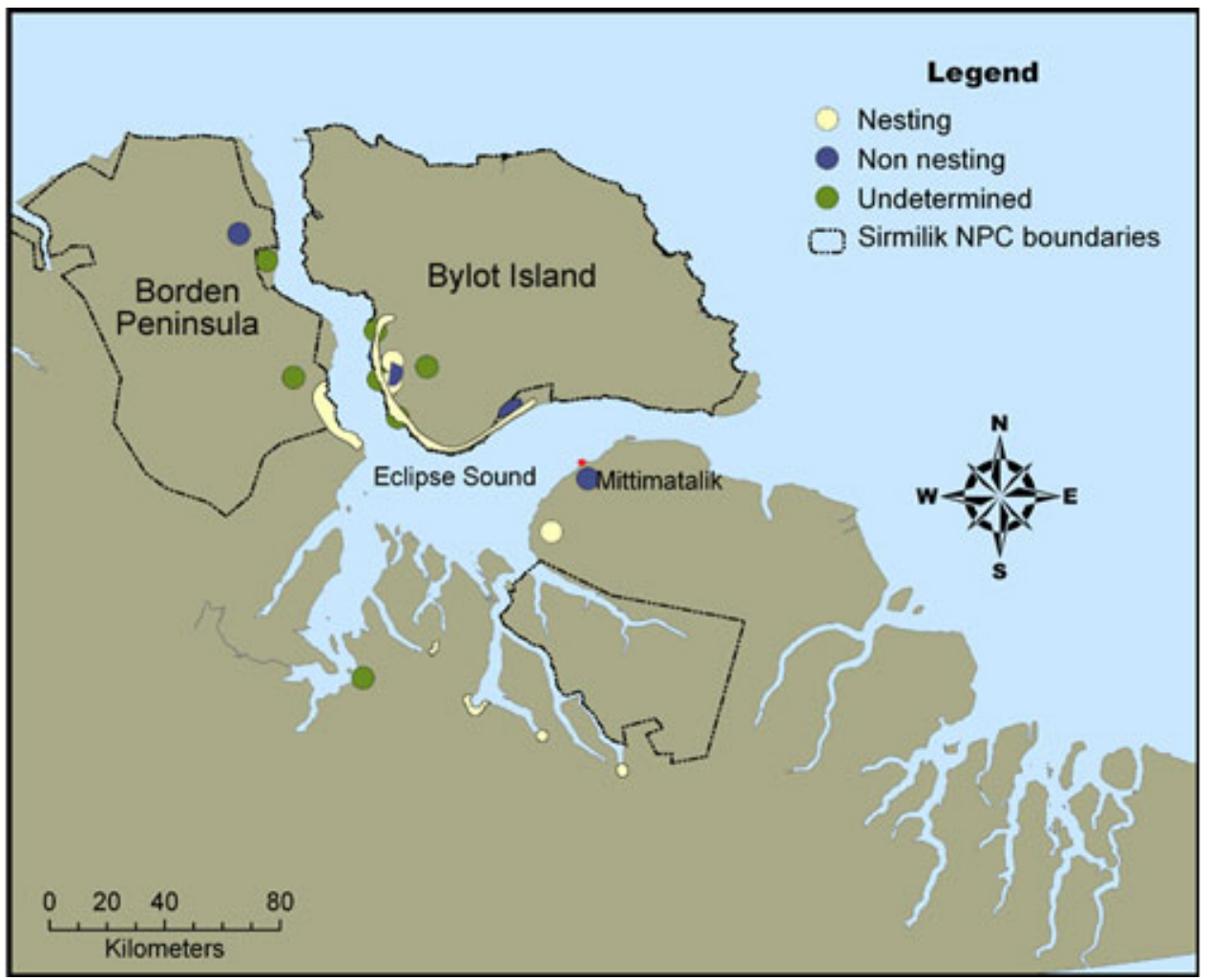

Many of the 15 informants made comments about goose distribution and abundance on Bylot Island: $8 / 15$ stated that the goose population on the island had declined, $3 / 15$ reported that geese are no longer restricted to Bylot, one did not observe any change, and 3/15 did not comment specifically about Bylot (Table 2). Descriptions of groups of geese so numerous that they looked like snow patches were recalled by six informants to illustrate a decline in certain areas. Comments were also made about geese being currently more abundant near the communities of Igloolik and Arctic Bay.

Ten informants provided timelines for when they started observing changes in goose distribution and/ or abundance, and 14 commented on the reasons they perceived to have caused the changes. Of the first group, 3/10 indicated that changes had been observed since biologists started the goose surveys in the region, $2 / 10$ had been noticing changes since the 1990s, and 2/10 had marked changes in recent years (Table 2). Disturbance because of research and the use of helicopters by biologists were cited by $11 / 14$ and $9 / 14$ informants, respectively, as the main cause of these changes, followed by disturbance because of hunting by the community, such as noise associated with snowmobiles and rifles, which was mentioned by 6/14 informants, and high hunting pressure in certain areas, which was cited by $4 / 14$ (Table 2 ).

According to scientific surveys conducted on spring staging grounds, the total greater snow goose population has grown from $<40,000$ birds in the mid-1960s to approximately 700,000 birds in 1997 (Reed et al. 1998). Aerial surveys conducted on 
Fig. 6. Fall and spring migration routes and feeding stopover sites of greater snow geese (Chen caerulescens atlantica), as reported by the local experts from Mittimatalik, Nunavut, Canada, interviewed in this study.

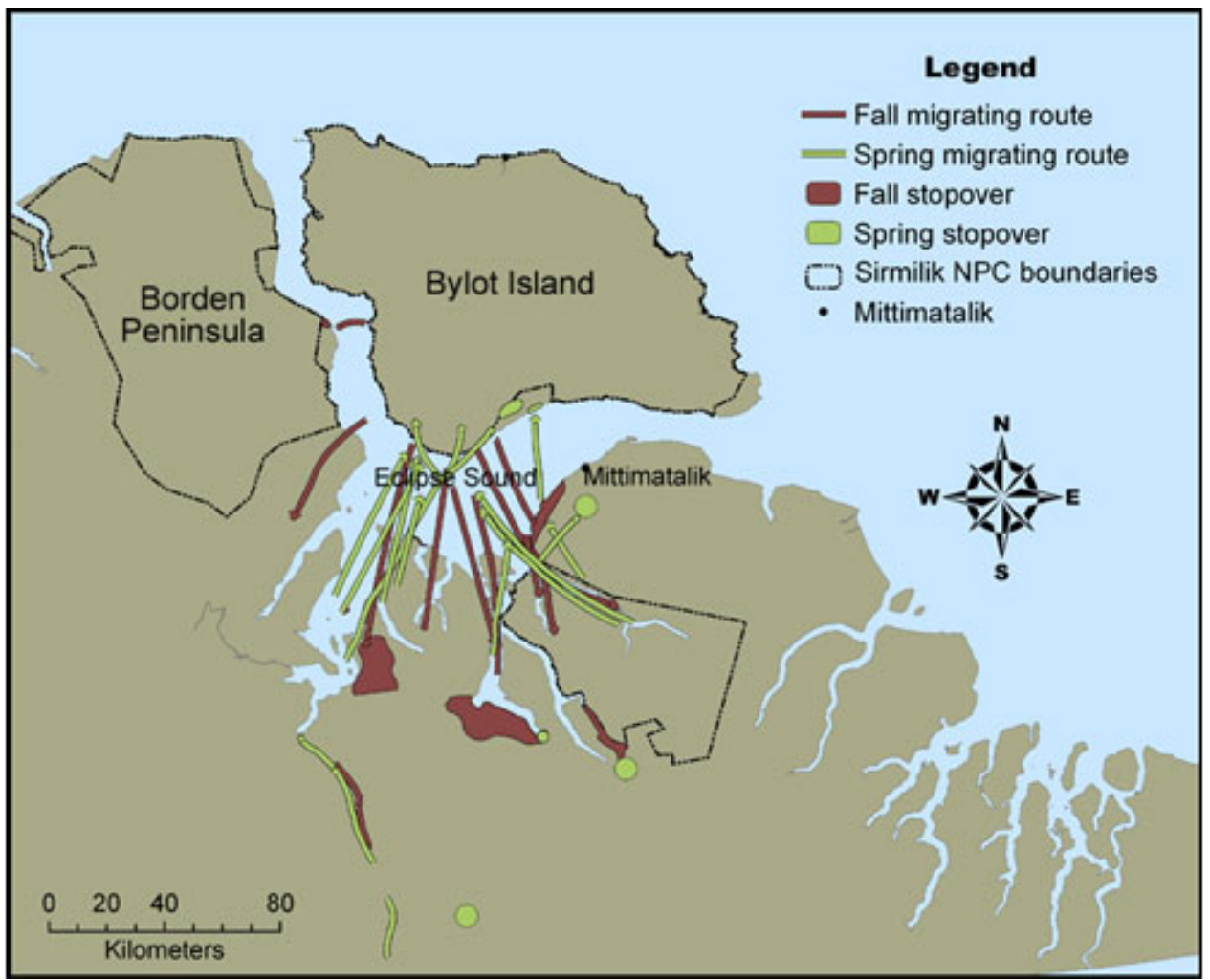

Bylot Island, from 1983 to 1993, also revealed an increase in the number of adult geese and goslings, which peaked in 1993 (Reed et al. 2002; see Appendix 1). Numbers decreased slightly between 1998 and 2003 but remained much higher than in 1983 (Reed et al. 2002, J. Lefebvre, unpublished data). These recent aerial surveys also showed that brood densities and distribution varied depending on goose abundance. The number of geese summering on Bylot Island is thought to be influenced by breeding success, which in turn may be strongly influenced by spring climatic conditions (Reed et al. 2004) and predation pressure (Bêty et al. 2002).

Over the last $20 \mathrm{yr}$, scientists have seen no evidence of consistent changes in the distribution of nesting sites used by snow geese on Bylot Island. Changes in distribution have been observed, but were always short-lived and are perceived to be related to specific annual causes such as local snow melt patterns (G. Gauthier, personal communication). Unpublished information dating back almost $40 \mathrm{yr}$ is, however, being analyzed that may show changes over this extended period (A. Reed, personal communication).

\section{DISCUSSION}

We found many cases of complementarity between the TEK we collected and current scientific knowledge. The integration of TEK and scientific knowledge expanded the spatial and temporal scales of documented scientific knowledge about arctic foxes and greater snow geese. However, TEK and scientific knowledge complemented each other more efficiently for foxes than for geese. We explain the reasons for this and address the similarities and 
Table 2. Summary of Inuit traditional ecological knowledge pertaining to changes in the abundance and distribution of greater snow geese (Chen caerulescens atlantica), as reported by 13 and 15 local experts from Mittimatalik, Nunavut, Canada, interviewed in this study, respectively. The temporal scale includes knowledge dating back to the 1940s, and the spatial scale is Bylot Island and the northern part of adjacent Baffin Island. Timelines for the observations based on reports from 10 experts and reasons perceived to have caused the changes based on reports by 14 experts are also summarized.

\begin{tabular}{|c|c|c|}
\hline Topic & Comments on population trend & Number of informants \\
\hline \multirow[t]{5}{*}{ Overall population trend } & The overall abundance did not change & 4 \\
\hline & More geese in general & 2 \\
\hline & Fewer geese in general & 2 \\
\hline & Don't know & 4 \\
\hline & There are interannual variations in goose abundance & 5 \\
\hline \multirow[t]{7}{*}{ Variations in distribution } & Geese are more scattered and have relocated & 12 \\
\hline & Increased goose abundance in specific areas & 10 \\
\hline & Decreased goose abundance in specific areas & 9 \\
\hline & Less concentrated on Bylot Island & 3 \\
\hline & Decline in numbers on Bylot Island & 8 \\
\hline & There are no changes in goose distribution & 1 \\
\hline & There are fewer non-nesting geese on Bylot & 1 \\
\hline \multirow[t]{6}{*}{ Timeline for the observations } & $\begin{array}{l}\text { Since goose biologists started their surveys on } \\
\text { Bylot Island (early 1980s to early 1990s) }\end{array}$ & 3 \\
\hline & Since the $1990 \mathrm{~s}$ & 2 \\
\hline & In recent years & 2 \\
\hline & $\begin{array}{l}\text { Since the extensive use of rifles and snowmobiles } \\
(1970 \text { s) }\end{array}$ & 1 \\
\hline & In comparison with childhood (1940s) & 1 \\
\hline & In comparison with childhood (1950s) & 1 \\
\hline \multirow[t]{3}{*}{ Reasons for changes } & Goose biologists doing their research & 11 \\
\hline & Use of helicopters & 9 \\
\hline & Hunting pressure in specific areas & 4 \\
\hline
\end{tabular}


Use of new loud equipment, e.g., snowmobiles and

rifles, to hunt geese

All the planes coming and going from Mittimatalik

Increase in fox population following the trapping decline

Geese hiding away
6

2

2

2 differences between TEK and scientific knowledge when both were available at the same scale. We close by discussing the implications of our study for wildlife resource management and for future research.

\section{Expansion of documented knowledge through the integration of traditional ecological knowledge and scientific observations}

TEK broadened current scales of scientific knowledge in several areas. For instance, TEK pertaining to the winter feeding ecology of arctic foxes expanded current scientific knowledge at both the spatial, i.e., from tens to hundreds of kilometers, and temporal, i.e., from summer to annual, scales. Scientific information is currently lacking regarding the winter diet of the regional fox population, and, because arctic fox are opportunistic omnivores that occupy various habitats, it is difficult to generalize from the few winter dietary data we have for other populations (Fay and Stephenson 1989, Angerbjörn et al. 1994, Roth 2002, Eide et al. 2005; Appendix 1). TEK added to our knowledge regarding the ecology of the regional fox population by providing: (1) evidence that local arctic foxes use a variety of habitats during winter, from land to sea ice; (2) an overview of foods consumed by local arctic foxes during the winter; (3) insight into the importance of seal pup consumption for arctic foxes in early spring in the area, and (4) insight into the existence of two distinct strategies, one marine and one terrestrial, that foxes use to take advantage of different winter resources in the area. TEK also provided information regarding differences in fur characteristics between foxes adopting these two strategies; to our knowledge, this has not been documented scientifically. The existence of two strategies has only been documented by scientists outside of this study region, wherein results were based on foxes' summer diets in areas in which foxes have access to large bird colonies (Fay and Stephenson 1989, Eide et al. 2005), or at a pan-arctic scale across fox populations living in very different habitats (Angerbjörn et al. 1994). Roth (2002, 2003) suggested that distinct segments of fox populations might use different winter foraging options, one terrestrial and one marine, based on the proportion of marine food in the diet of arctic foxes from Hudson Bay, Canada. However, his analysis found no evidence of the two strategies among this population.

At the regional scale, TEK complemented current scientific knowledge about fox denning locations by extending known denning sites to an area of $\sim 23,000 \mathrm{~km}^{2}$ compared to the $425-\mathrm{km}^{2}$ area studied on Bylot Island. In areas in which the spatial scales of TEK and scientific knowledge were the same, e. g., the south plain of Bylot Island, scientific knowledge was more detailed at locating denning sites.

In the case of the greater snow goose, TEK extended the spatial scale of scientific knowledge about the molting locations and migration stopovers used by geese. Molting areas outside of Bylot Island covering approximately 13,000 and $22,000 \mathrm{~km}^{2}$ used for migration stopovers were identified. However, recent scientific surveys provided information on major molting locations and potential stopover sites (A. Reed and M. R. Evans, personal communication) located 200-250 km south of Bylot Island. These locations were unknown to the local experts we interviewed. This exposes a limit to the spatial extent of regional TEK. Data from satellite telemetry also determined the migration patterns of some individual geese over continental distances. For the most part, though, 
TEK and scientific observations regarding the molting cycle and migration pattern of geese covered similar seasonal and regional scales.

There was a large degree of overlap between the temporal and spatial scales of TEK and scientific observations on the topics of regional goose abundance and distribution. For goose distribution, TEK presented some spatial complementarity to scientific observations by providing information on sites outside of Bylot Island, thus extending the documented observations to $\sim 14,000 \mathrm{~km}^{2}$. Comments on localities beyond the Mittimatalik region, in which people have observed increases in goose populations, also broadened the spatial scale of observations outside the region. Although TEK also provided a historical perspective on goose abundance by extending the observation period to $65 \mathrm{yr}$, compared to the $25 \mathrm{yr}$ covered by scientific surveys, most TEK extended approximately $25 \mathrm{yr}$. When investigating goose abundance and distribution on Bylot Island, TEK provided smallscale details on changes in goose distribution at specific sites, whereas systematic detailed scientific surveys covered the entire south plain of the island. Through population surveys of spring staging areas, scientific investigations also provided information on the overall greater snow goose population on a continental scale and an annual time scale extending beyond the regional and seasonal TEK.

Our results highlight prominent differences in the level of spatio-temporal complementarities between TEK and scientific knowledge when investigating the ecology of arctic foxes vs. that of snow geese. In the case of arctic foxes, detailed scientific studies have been conducted over a relatively short period, i.e., < $10 \mathrm{yr}$, on a limited geographical scale, i.e., the south plain of Bylot Island, and examined a few specific topics during the summer. Alternatively, local people have had a high level of familiarity with the species because of the extensive fur trapping era that lasted until the 1980s and through year-round contact with the species. In addition, Inuit from north Baffin Island traditionally lived in camps spread out over vast and flexible territories (Brody 1976, Mary-Rousselière 1985). Local conditions encouraged the use of vast territories, including the large spatial distribution of hunted animal populations, the presence of sea ice that facilitated travel, the low local human densities, and fur trading activities that encouraged families to spread over the landscape and make periodic long journeys to trading posts (Brody 1976). Since settlement, the people of Mittimatalik have continued to hunt over a large territory, which was estimated at approximately 96,200 km² in 1991 (Riewe 1991).

Many studies integrating both scientific knowledge and TEK found that TEK generally provided information at more local geographical scales (Table 1). In contrast, our study of the arctic fox found that TEK broadened the spatial context of scientific data. However, as scientific investigation continues and progresses, the degree of overlap in the spatial and temporal coverage of TEK and regional scientific knowledge will likely increase.

The situation is different for the snow goose because scientific research has been conducted on a variety of relevant topics for nearly $20 \mathrm{yr}$ and, although centered on Bylot Island, has involved exploratory studies in other northern regions. Local people are less familiar with geese than with foxes because geese have never been an essential source of food or income. Also, because geese are summer Arctic residents, local observations overlap with active research in the area. Thus there is a high degree of overlap in the spatial and temporal coverage of TEK and scientific knowledge regarding geese. Migratory and wintering area research also allows scientists to extend their spatial and temporal knowledge about geese well beyond the reach of TEK, as is the case for most migratory birds. This has obvious implications regarding the selection of likely cases for useful complementarity.

\section{Traditional ecological and scientific knowledge from similar scales}

Although our main objective was to document TEK that was complementary to scientific knowledge, there were often overlaps in the spatial and temporal scales of the two types of knowledge. Examples include knowledge about the arrival of red fox in the region, factors that favor the establishment of fox dens, the timing of goose molt and migration, and changes in goose abundance. When overlap in scales exist, comparisons between TEK and scientific knowledge are important to assess confidence in individual conclusions (Huntington et al. 2004a). Agreement was found between TEK and scientific knowledge concerning the arrival of the red fox around Mittimatalik, factors that favor den establishment, and the timing of goose molt and migration. For all these subjects, comparison of the two types of data allowed us to cross-validate 
information from both sources of knowledge (Fabricius et al. 2006). Regarding red fox arrival, the information from both sources was often very similar; the earliest sighting reported by informants dated back to 1947-1948 and coincided exactly with the year that the first red fox pelt was traded by the Hudson Bay Company in Mittimatalik (Macpherson 1964). These two sources of information, however, may not be independent.

Disagreement between TEK and scientific knowledge was also found with regard to, for example, changes in goose abundance. Scientific surveys performed on Bylot Island document a more than threefold increase in the goose population from 1983 to 1993 (Reed et al. 2002), whereas eight of the 15 informants reported a decline in goose abundance on the island in recent decades. This contradiction is difficult to explain. Scientific surveys have reported a slight decrease in abundance since a local population peak was reached in 1993. Perhaps the overall decrease in goose abundance noted by informants was based on comparisons between present times and the 1993 benchmark. However, many informants reported noticing a decline prior to the 1980s. However, both scientists and TEK experts agree that there is interannual variability in the abundance and distribution of goose nests. Because of the gregarious nature of geese, short-term changes in abundance, which are not to be confounded with long-term trends, are probably highly perceptible in certain sites. Local experts' perceptions of regional abundance may thus be based on observations from very specific sites (Fig. 7). Further exploration of both TEK and scientific knowledge, e.g., survey data dating back $40 \mathrm{yr}$, is needed to allow an increased understanding of the changes in local goose abundance, and to clarify if these changes have occurred for nesting or brood-rearing geese, whose population sizes seem to vary independently.

There was a high degree of variability in informants' comments about goose abundance. Variability in the TEK collected on a given subject can emerge from many sources, such as methodological errors related to the choice of informants, errors in interpretation and translation, errors stemming from the recollection of specific facts by informants, a reluctance to reveal sensitive knowledge, or variations in land use between informants (Cutler 1970, Ferguson and Messier 1997, Huntington 2000). The issues of variability and errors while documenting TEK have been discussed in the literature (Ferguson and Messier 1997, Huntington 2000). Although the credibility of scientific information has also been discussed, the peer review process, though not infallible, ensures a standard of credibility (Huntington et al. 2004a).

Throughout this study, we took several measures to minimize sources of error when documenting TEK. These included the careful selection of participants and interpreter (see Ferguson and Messier 1997, Huntington 2000), data validation, and community verification, which is analogous to the scientific peer review (Huntington et al. 2004a). Nevertheless, variability remained in the comments of informants regarding certain topics, such as changes in goose abundance and the arrival of the red fox. Some of this variability clearly originated from the variable experiential knowledge of local people. For example, the high variability that existed in accounts of the timing of the arrival of red foxes in the Mittimatalik region was not surprising, given the very low density of a species when it first colonizes an area. In the Mittimatalik area, the fact that, until the $1960 \mathrm{~s}$, most informants lived in isolated camps spread over a large area could further explain differences in the timing of their first red fox sightings. The age of informants also explained part of the variability, because younger informants believed red foxes had always been around. Variation in reports of goose abundance could be because of perceptions of population abundance based on localized observations at very specific sites that experience natural interannual variation in goose abundance.

Although we had not expected that the topic of geese would be subject to local tensions, documentation of TEK revealed some distrust of goose biologists, who were often blamed for the decline in goose abundance or change in their distribution (Table 2). Many interviewees stated that geese are easily upset and prefer quiet places, and thus have moved away from the sound of helicopters and research activities such as collaring, i.e., marking geese with individually coded plastic neck collars. Similar comments were expressed by Yup'ik elders from southwestern Alaska, who associated a decline in black brant goose (Branta bernicla nigricans) populations with the presence of biologists (FienupRiordan 1999). Fienup-Riordan (1999) highlighted the difference between the Yup'ik elders' view of geese as sentient beings and the non-native view of geese as study subjects. She also illustrated the resentment local people felt toward nonlocal control 
Fig. 7. Changes in the abundance and distribution of greater snow geese (Chen caerulescens atlantica), as reported by the local experts from Mittimatalik, Nunavut, Canada, interviewed in this study. The temporal scale includes knowledge dating back to the 1940s, and the spatial scale is Bylot Island and the northern part of adjacent Baffin Island. Black arrows indicate the movements of geese toward higher ground and the western side of the south plain of Bylot Island.

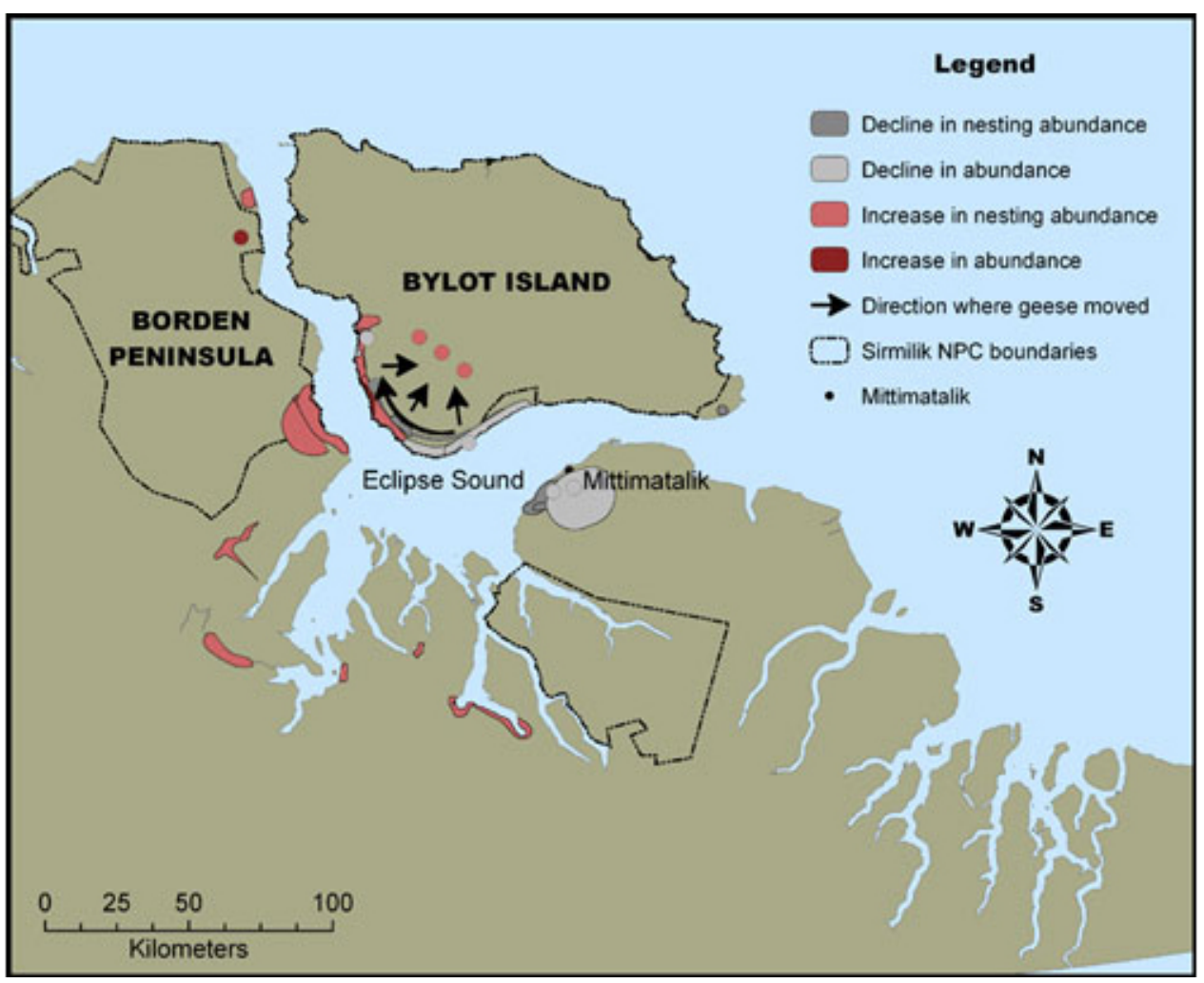

over resources, and the difficulty that wildlife managers can have in accommodating traditional beliefs within conservation objectives. Our interviews opened the door for some informants to express their bitterness toward biologists. This resentment toward outside researchers might help explain why some hunters were reluctant or refused to participate in our interviews. We do not think that those who participated biased our results because of these existing tensions, but we cannot verify this. Since 2002, goose biologists and local representatives have annually met to discuss and participate in the co-management process of Sirmilik NPC. Since 2005, biologists have also organized annual workshops in Mittimatalik to present their research and discuss their results with the community. During these meetings, goose biologists have presented their survey results, which show an increase in goose abundance, and their view that the research process does not have adverse impacts on geese (G. Gauthier, personal communication). These presentations have not entirely changed the unfavorable perception many local people have of the goose research program. According to Fienup-Riordan (1999), education of local people without their total collaboration may "ring hollow to local ears." Further exploration of this issue is needed.

\section{Implications for resource management and future research}

Collecting TEK by focusing on information complementary to scientific knowledge has helped us to identify several areas of convergence between 
TEK and current scientific knowledge (see Riedlinger and Berkes 2001). First, TEK provided spatial and temporal viewpoints that scientific knowledge lacked. Second, TEK provided several new insights into ecological understanding and exposed new research opportunities that we think would have gone unnoticed had we collected TEK and compared it with scientific observations at similar scales. The major drawback of focusing on complementarities, however, is that it decreases the possibility for the cross-validation of knowledge.

We have attempted to combine TEK and scientific knowledge from a strictly factual ecological standpoint. However, TEK also comprises values, ethics, and epistemologies that are essential to the management of natural resources (Usher 2000, Houde 2007). This perhaps represents the most important area of complementarity with scientific knowledge. If this is accepted, then the factual aspect of TEK, which is easier to explore (Houde 2007), can be viewed as a starting point from which communication and shared trust can be built (Berkes et al. 2006). For this reason, our research process was not seen as a one-way transfer of knowledge (Fabricius et al. 2006). Rather, it was another step toward mutual understanding among the local population, scientists, and Parks Canada staff that will hopefully strengthen the relationships that link these three primary participants in the comanagement of local natural resources.

Currently, arctic foxes and geese are not subject to active wildlife management in the Mittimatalik region. Therefore, it is difficult to evaluate how theory would influence practice in regard to integrating TEK and scientific knowledge for the management of these resources. Given the ecological importance of these two species in the recently created Sirmilik NPC, the early articulation of TEK and scientific knowledge will hopefully smooth the integration process when joint management decisions need to be made.

\section{CONCLUSIONS}

We have shown that, when investigating factual ecological knowledge, the degree of complementarity between TEK and ecological science largely depended on the spatial and temporal scales from which each type of knowledge was derived. Complementarity was greater for knowledge of arctic fox ecology than for greater snow goose ecology. This difference between the two species was likely generated by three factors that influenced the degree of overlap between the spatial and temporal scales of observations forming the basis of TEK vs. scientific knowledge. These three factors include the history of local scientific investigations, the type of interaction between local experts and the species, and the natural history characteristics of each species. We conclude that future complementarity research could more efficiently select cases based on a priori examination of the temporal and spatial scales of both types of knowledge.

To gain the most benefits from complementarity, a strategic cycling between the collection of TEK and the acquisition of scientific knowledge could be organized to enhance our overall knowledge about the ecology of a given wildlife population. For example, TEK collected during this study expanded our knowledge about the ecology of the regional fox population by providing evidence that local arctic foxes use both the tundra and sea ice in winter. This was not documented by scientists working locally. However, since this study was performed, some Bylot Island foxes have been fitted with satellite transmitters (D. Berteaux, unpublished data). The scientific knowledge provided by satellite data was congruent with TEK. The satellite data also showed how individual foxes use terrestrial and marine habitats throughout the winter, knowledge that is largely inaccessible to local experts, who cannot easily differentiate between individual foxes seen at different locations. In contrast, satellite data cannot provide behavioral or dietary information. Local experts could help interpret satellite data using TEK, leading to further novel research projects that may, in turn, again benefit from collecting additional TEK. If designed strategically, this cycle of enquiry can help overall knowledge grow more quickly than can the input of either local hunters or scientists alone. Furthermore, the involvement of local experts in all stages of the cycle can increase the likelihood that research will address topics that are locally relevant and that results will be transferred to local communities. If designed collaboratively, this partnership may also help strengthen mutual understanding between scientists and local inhabitants.

At a time when TEK research is still looking for novel approaches for the integration of various types of knowledge, we believe that understanding the scales at which TEK and scientific observations operate is vital, and that bridging both scales and 
knowledge types (see Berkes et al. 2006) will maximize the benefits from the articulation of TEK and scientific knowledge.

Responses to this article can be read online at: http://www.ecologyandsociety.org/voll4/iss2/art19/ responses/

\section{Acknowledgments:}

We acknowledge with sincere regards the elders and hunters who shared their knowledge throughout the project: M. Akomalik, T. Aksarjuq, H. Kadloo, A. J. Katsak, I. Katsak, G. Kilukishak, M. Koonark, B. Koonoo, J. Koonoo, R. Koonoo, A. Mucktar, T. Mucktar, C. Nutarak, T. Nutarariaq, E. Ootoova, E. Panipakoocho, J. Peterlossie, P. A. Peterlossie, M. Qaunaq, P. Sangoya, and R. Sangoya. The authors are also grateful to T. Arnakallak, L. Pewatoalook, E. Pewatoalook, I. Quasa, L. Quasa, S. Elverum, and L. Ootova for translation and/or assistance, as well as to the community of Mittimatalik, the Mittimatalik Inuit Knowledge Working Group, the Nunavut Field Unit of Parks Canada, and the staff from SirmilikNPC who kindly supported the project. Comments from Kenneth F. Abraham, Fikret Berkes, Matthew R. Evans, Marie Fast, Lorraine Goyette, Austin Reed, Gilles Gauthier, and two anonymous reviewers considerably improved the quality of the manuscript. Funding was provided by Parks Canada; FQRNT (Quebec government); the Northern Ecosystem Initiative (Environment Canada); the Nunavut Wildlife Management Board; the Canada Network of Centers of Excellence ArcticNet; NSERC; the Canada Research Chair Program, the Université du Québec à Rimouski, Centre d'études nordiques; the Department of Culture, Language, Elders and Youth (Government of Nunavut); and the Polar Continental Shelf Project. This is publication no. 02009 of the Polar Continental Shelf Project. Seven elders who participated to this project passed away before this paper was published. We dedicate our work to their memory.

\section{LITERATURE CITED}

Abraham, K. F. 1980. Moult migration of lesser snow geese. Wildfowl 31:89-93.

Agrawal, A. 1995. Dismantling the divide between indigenous and scientific knowledge. Development and Change 26:413-439.

Angerbjörn, A., P. Hersteinsson, K. Liden, and E. Nelson. 1994. Dietary variation in arctic foxes (Alopex lagopus): an analysis of stable carbon isotopes. Oecologia 99:226-232.

Aswani, S., and R. J. Hamilton. 2004. Integrating indigenous ecological knowledge and customary sea tenure with marine and social science for conservation of bumphead parrotfish (Bolbometopon muricatum) in the Roviana Lagoon, Solomon Islands. Environmental Conservation 31:69-83.

Bart, D. 2006. Integrating local ecological knowledge and manipulative experiments to find the causes of environmental change. Frontiers in Ecology and the Environment 4:541-546.

Bergmann, A., H. Hinz, R. E. Blyth, M. J. Kaiser, S. I. Rogers, and M. Armstrong. 2004. Using knowledge from fishers and fisheries scientists to identify possible groundfish "essential fish habitats." Fisheries Research 66:373-379.

Berkes, F. 2008. Sacred ecology: traditional ecological knowledge and resource management. Second edition. Routledge, New York, New York, USA.

Berkes, F., and C. Folke, editors. 1998. Linking social and ecological systems: management practices and social mechanisms for building resilience. Cambridge University Press, Cambridge, UK.

Berkes, F., W. V. Reid, T. J. Wilbanks, and D. Capistrano. 2006. Bridging scales and knowledge systems. Pages 315-331 in W. V. Reid, F. Berkes, T. J. Wilbanks, and D. Capistrano, editors. Bridging scales and knowledge systems: concepts and applications in ecosystem assessment. Island Press, Washington, D.C., USA.

Bêty, J., G. Gauthier, and J. F. Giroux. 2003. Body condition, migration, and timing of reproduction in snow geese: a test of the condition-dependent model 
of optimal clutch size. American Naturalist 162:110-121.

Bêty, J., G. Gauthier, E. Korpimaki, and J. F. Giroux. 2002. Shared predators and indirect trophic interactions: lemming cycles and arctic-nesting geese. Journal of Animal Ecology 71:88-98.

Blouin, F. 1996. Suivi de la migration automnale de la grande oie blanche à l'aide de la télémétrie par satellite. Dissertation. Université du Québec à Montréal, Montreal, Quebec, Canada.

Brody, H. 1976. Inuit land use in North Baffin Island and northern Foxe Basin. Pages 153-172 in M. M. R. Freeman, editor. Inuit land use and occupancy project. Volume 3. Department of Indian and Northern Affairs, Ottawa, Ontario, Canada.

Chirkova, A. F. 1968. The relationship between arctic fox and red fox in the far North. Problems of the North 11:111-113.

Creswell, J. W. 1998. Qualitative inquiry and research design: choosing among five traditions. Sage, Thousand Oaks, California, USA.

Cutler, W., III. 1970. Accuracy in oral history interviewing. Historical Methods Newsletter 3:1-7.

Eide, N. E., P. M. Eid, P. Prestrud, and J. E. Swenson. 2005. Dietary responses of arctic foxes Alopex lagopus to changing prey availability across an Arctic landscape. Wildlife Biology 11:109-121.

Environment Canada. 2005. Terrestrial ecozones of Canada. Available online at: http://www.ec.gc.ca/ soer-ree/English/Framework/Nardesc/canada e.cfm? $\underline{\text { StrPrint }=\text { true \&. }}$.

Fabricius, C., R. Scholes, and G. Cundill. 2006. Mobilizing knowledge for integrated ecosystem assessments. Pages 165-182 in W. V. Reid, F. Berkes, T. J. Wilbanks, and D. Capistrano, editors. Bridging scales and knowledge systems: concepts and applications in ecosystem assessment. Island Press, Washington, D.C., USA.

Fay, F. H., and R. O. Stephenson. 1989. Annual, seasonal, and habitat-related variation in feedinghabits of the arctic fox (Alopex-Lagopus) on StLawrence-Island, Bering Sea. Canadian Journal of Zoology 67:1986-1994.
Ferguson, M. A. D., and F. Messier. 1997. Collection and analysis of traditional ecological knowledge about a population of Arctic tundra caribou. Arctic 50:17-28.

Ferguson, M. A. D., R. G. Williamson, and F. Messier. 1998. Inuit knowledge of long-term changes in a population of Arctic tundra caribou. Arctic 51:201-219.

Fienup-Riordan,A. 1999. Yagulget qaillun pilartat (what the birds do): Yup'ik Eskimo understanding of geese and those who study them. Arctic 52:1-22.

Fraser, D. J., T. Coon, M. R. Prince, R. Dion, and L. Bernatchez. 2006. Integrating traditional and evolutionary knowledge in biodiversity conservation: a population level case study. Ecology and Society 11(2): 4. [online] URL: http://www.ecologyandsociety. org/vol11/iss2/art4/.

Furgal, C. M., S. Innes, and K. M. Kovacs. 1996. Characteristics of ringed seal, Phoca hispida, subnivean structures and breeding habitat and their effects on predation. Canadian Journal of Zoology 74:858-874.

Gagnon, C.-A. 2007. Complémentarité entre savoir écologique inuit et connaissances scientifiques: le cas de l'écologie du renard arctique, du renard roux et de la grande oie des neiges dans la région de Mittimatalik, Nunavut, Canada. Dissertation. Université du Québec à Rimouski, Rimouski, Quebec, Canada. Available online at: http://wer.uq ar.qc.ca/chaires/chairedb/documents/M.Sc.Gagnon2007. pdf.

Gagnon, C.-A., and D. Berteaux. 2006. Integrating traditional and scientific knowledge: management of Canada's national parks. Pages 209-221 in R. Riewe and J. Oakes, editors. Climate change: integrating traditional and scientific knowledge. Aboriginal Issues Press, Winnipeg, Manitoba, Canada.

Gagnon, C.-A., M.-C. Cadieux, G. Gauthier, E. Lévesque, A. Reed, and D. Berteaux. 2004. Analyses and reporting on 15 years of biological monitoring from Bylot Island, Sirmilik National Park of Canada. Université Laval, Quebec City, Quebec, Canada.

Gauthier, G., L. Rochefort, and A. Reed. 1996. The exploitation of wetland ecosystems by 
herbivores on Bylot Island. Geoscience Canada 23:253-259.

Gilchrist, G., J. Heath, L. Arragutainaq, G. Robertson, K. Allard, S. Gilliland, and $M$. Mallory. 2006. Combining scientific and local knowledge to study common eider ducks wintering in Hudson Bay. Pages 189-201 in R. Riewe and J. Oakes, editors. Climate change: integrating traditional and scientific knowledge. Aboriginal Issues Press, Winnipeg, Manitoba, Canada.

Gilchrist, G., M. Mallory, and F. Merkel. 2005. Can local ecological knowledge contribute to wildlife management? Case studies of migratory birds. Ecology and Society 10(1): 20. [online] URL: http://www.ecologyandsociety.org/vol10/iss1/art20/

Grenier, L. 1998. Connaissances indigènes et recherche: un guide à l'intention des chercheurs. International Development Research Centre, Ottawa, Ontario, Canada.

Hammill, M. O., and T. G. Smith. 1991. The role of predation in the ecology of the ringed seal in Barrow Strait, Northwest Territories, Canada. Marine Mammal Science 7:123-135.

Houde, N. 2007. The six faces of traditional ecological knowledge: challenges and opportunities for Canadian co-management arrangements. Ecology and Society 12(2): 34. [online] URL: http: //www.ecologyandsociety.org/vol12/iss2/art34/.

Huntington, H. P. 1998. Observation on the utility of the semi-directive interview for documenting traditional ecological knowledge. Arctic 51:237-242.

Huntington, H. P. 2000. Using traditional ecological knowledge in science: methods and applications. Ecological Applications 10:1270-1274.

Huntington, H. P., T. Callaghan, S. Fox, and I. Krupnik. 2004a. Matching traditional and scientific observations to detect environmental change: a discussion on Arctic terrestrial ecosystems. Ambio 13 (Special Report):18-23.

Huntington, H. P., R. S. Suydam, and D. H. Rosenberg. 2004b. Traditional knowledge and satellite tracking as complementary approaches to ecological understanding. Environmental Conservation 31:177-180.
Inuit Knowledge Project. 2009. Using Inuit knowledge in management, research and monitoring of Nunavut national parks. Available online at: $\underline{\text { http://www.lecol-ck.ca/index.php?pid=10 }}$

Johnson, M., editor. 1992. Lore: capturing traditional environmental knowledge. Dene Cultural Institute and International Development Research Centre, Ottawa, Ontario, Canada.

Kempf, C., X. Harmel, B. Sittler, and A. Piantanida, editors. 1978. Notes géomorphologiques, ornithologiques et mammalogiques sur l'île Bylot et la région de Pond Inlet, Canada. Rapport d'expédition 1977. Groupe de recherche en écologie arctique, Scheltigheim, France.

Levin, S. A. 1992. The problem of pattern and scale in ecology. Ecology 73:1943-1967.

Levin, S. A. 2000. Multiple scales and the maintenance of biodiversity. Ecosystems 3:498-506.

Lyver, P. O. B. 2002. Use of traditional knowledge by Rakiura Maori to guide sooty shearwater harvests. Wildlife Society Bulletin 30:29-40.

Macpherson, A. H. 1964. A northward range extension of the red fox in the eastern canadian Arctic. Journal of Mammalogy 45:138-140.

Mallory, M. L., H. G. Gilchrist, A. J. Fontaine, and J. A. Akearok. 2003. Local ecological knowledge of ivory gull declines in Arctic Canada. Arctic 56:293-298.

Mary-Rousselière, G. 1985. Factors affecting human occupation of the land in the Pond Inlet region from prehistoric to contemporary time. Eskimo 41:8-24.

Mauro, F., and P. D. Hardison. 2000. Traditional knowledge of indigenous and local communities: international debate and policy initiatives. Ecological Applications 10:1263-1269.

Miles, M. B., and M.A. Huberman. 2003. Analyse de données qualitatives. Série Méthodes en sciences humaines. De Boeck, Brussells, Belgium.

Moller, H., F. Berkes, P. O. Lyver, and M. Kislalioglu. 2004. Combining science and 
traditional ecological knowledge: monitoring populations for co-management. Ecology and Society 9(3): 2. [online] URL: http://www.ecologya ndsociety.org/vol9/iss3/art2/.

Mowbray, T. B., F. Cooke, and B. Ganter. 2000. Snow goose (Chen caerulescens). In A. Poole, editor. The Birds of North America Online. Cornell Laboratory of Ornithology, Ithaca, New York, USA.

Nadasdy, P. 2003. Reevaluating the comanagement success story. Arctic 56:367-380.

Nakashima, D. J. 1991. The ecological knowledge of Belcher Island Inuit: a traditional basis for contemporary wildlife co-management. Dissertation. McGill University, Montreal, Quebec, Canada.

Neis, B., D. C. Schneider, L. Felt, R. L. Haedrich, J. Fischer, and J. A. Hutchings. 1999. Fisheries assessment: What can be learned from interviewing resource users? Canadian Journal of Fisheries and Aquatic Sciences 56:1949-1963.

Priest, H., and P. J. Usher. 2004. Final report of the Nunavut wildlife harvest study. Nunavut Wildlife Management Board, Iqaluit, Nunavut, Canada. Available online at: http://www.nwmb.com/ english/resources/harvest study/NWHS\%202004\% 20Report.pdf.

Reed, A., J.-F. Giroux, and G. Gauthier. 1998. Population size, productivity, harvest, and distribution. Pages 5-31 in D. J. Batt, editor. The greater snow goose: report of the Arctic Goose Habitat Working Group. Arctic Goose Joint Venture Special Publication. U.S. Fish and Wildlife Service, Washington, D.C., USA, and Canadian Wildlife Service, Ottawa, Ontario, Canada.

Reed, A., R. J. Hughes, and H. Boyd. 2002. Patterns of distribution and abundance of greater snow geese on Bylot Island, Nunavut, Canada, 1983-1998. Wildfowl 53:53-65.

Reed, E. T., J. Bety, J. Mainguy, G. Gauthier, and J. F. Giroux. 2003. Molt migration in relation to breeding success in greater snow geese. Arctic 56:76-81.

Reed, E. T., G. Gauthier, and J. F. Giroux. 2004. Effects of spring conditions on breeding propensity of greater snow goose females. Animal Biodiversity and Conservation 27:35-46.
Riedlinger, D., and F. Berkes. 2001. Contributions of traditional knowledge to understanding climate change in the Canadian Arctic. Polar Record 37:315-328.

Riewe, R. 1991. Inuit use of the sea ice. Arctic and Alpine Research 23:3-10.

Riewe, R., editor. 1992. Nunavut atlas. Canadian Circumpolar Institute and the Tungavik Federation of Nunavut, Edmonton, Alberta, Canada.

Robertson, H. A., and T. K. McGee. 2003. Applying local knowledge: the contribution of oral history to wetland rehabilitation at Kanyapella Basin, Australia. Journal of Environmental Management 69:275-287.

Robinson, D. B. 2005. Fur trade. Pages 689-693 in M. Nuttall, editor. Encyclopedia of the Arctic. Routledge, New York, New York, USA.

Roth, J. D. 2002. Temporal variability in arctic fox diet as reflected in stable-carbon isotopes; the importance of sea ice. Oecologia 133:70-77.

Roth, J. D. 2003. Variability in marine resources affects arctic fox population dynamics. Journal of Animal Ecology 72:668-676.

Smith, T. G. 1976. Predation of ringed seal pups (Phoca hispida) by the arctic fox (Alopex lagopus). Canadian Journal of Zoology 54:1610-1616.

Stevenson, M. G. 1996. Indigenous knowledge in environmental assessment. Arctic 49:278-291.

Szor, G., D. Berteaux, and G. Gauthier. 2008 . Finding the right home: distribution of food resources and terrain characteristics influence selection of denning sites and reproductive dens in arctic foxes. Polar Biology 31:351-362.

Turner, N. J., M. B. Ignace, and R. Ignace. 2000. Traditional ecological knowledge and wisdom of aboriginal peoples in British Columbia. Ecological Applications 10:1275-1287.

Usher, P. J. 2000. Traditional ecological knowledge in environmental assessment and management. Arctic 53:183-193.

Wiens, J. A. 1989. Spatial scaling in ecology. Functional Ecology 3:385-397. 
Wilbanks, T. J. 2006. How scale matters: some concepts and findings. Pages 21-35 in W. V. Reid, F. Berkes, T. J. Wilbanks, and D. Capistrano, editors. Bridging scales and knowledge systems: concepts and applications in ecosystem assessment. Island Press, Washington, D.C., USA. 
Appendix 1. Detailed discussion of the international scientific literature concerning the winter feeding ecology and distribution of arctic foxes (Vulpes lagopus), the relationship between arctic and red foxes (Vulpes vulpes), as well as the molting cycle, migration pattern and distribution and abundance of greater snow geese (Chen caerulescens atlantica). Since Bylot Island is a very important study site for the latter species, most literature reviewed pertains to the area of Mittimatalik, although references to other areas are also mentioned.

Please click here to download file 'appendix1.pdf'. 
Appendix 2. Series of questions used as guide for the semi-directive interviews held during the first phase of the research, from May to September 2005.

Please click here to download file 'appendix2.pdf'. 
Appendix 3. Biographical and land use pattern information concerning the elders and hunters consulted during the project. This information provided a temporal and spatial context for the TEK recorded.

Please click here to download file 'appendix3.pdf'. 